\title{
An Initial Study Of Laundry Industrial Effects To The Water Pollution In East Jakarta
}

\author{
Titia Izzati ${ }^{1}$, Wiwit Suprihatiningsih ${ }^{2}$, Michael Kristovorus ${ }^{3}$, \\ Aldo Giovanni Andrean ${ }^{3}$ \\ ${ }^{1}$ Industrial Engineering Program, Engineering Faculty, Mercu Buana University, 11650, Indonesia \\ ${ }^{2}$ Mechanical Engineering Program, Engineering Faculty, Mercu Buana University, 11650, Indonesia \\ ${ }^{3}$ Young Researcher Program, Mardiana and Youth Research Center, 13810, Indonesia
}

\begin{abstract}
The research has been conducted by using the laundry liquid waste. The purpose of this research is to find out the solids in the laundry liquid water in a particular area such as East Jakarta and Central Jakarta. The result shown that level of the solids has been dissolved in ground water it was from 0.19 to 0.34 . The level of the solids the one has been dissolved to laundry waste tend to be cloudy (not clear) with TDS (ppt) from 0.13 to 0.86. Whereas liner obtained from the sample of laundry water (before and after laundry process) tend to high.
\end{abstract}

Keyword: TDS, Liquid waste, Waste Influence.

\section{Introduction}

Nowadays a lot of homes laundry services are growing rapidly over population growth and Industries especially in particular area such as East Jakarta[1,2]. East Jakarta is one of the areas in state of Jakarta which include having largest population[3]. By having home laundry businesses increased of environmental pollution in East Jakarta areas will increase[4-7].

The most laundry businesses exist around the crowded housing area[5, 8]. Since the issues of the low education level of young people and the rose of the social welfare in the society[9, 10], the emergence of home laundry business actually has good benefits. However, the growth of this laundry activities was not followed by a good waste water treatment so giving a negative impact to the environment [7, 11].

Liquid waste on the laundry water lot $\mathrm{s}$ contain the remnant of detergent, fragrances, clothes softener, and bleach which is very dangerous. Additionally, the laundry liquid waste has been used to wash it was a lot of solids substances contain such minerals, metals that are very dangerous and harmful for the health of the environment. Nearly all this laundry businesses discharge the waste through a sewer or the body of water without being processed first so that it will pollute the environment[12]. This is causes an imbalance of the biota that are located along the gutters included the solids which is dissolved in the laundry water and absorbed into the ground[13-15]. In the other hand, the open space in East Jakarta is limited[16].

Most population housing using ground water. Therefore, the laundry liquid waste is absorbed into the soil or the ground. It will be danger for the most of the population surrounding the ventures[17]. Because the most of the population ground water for daily needs such as bathing, washing the dishes, and water for consumption[5, 18]. In this issue, TDS (ppt) water is very influential to water drinking for surrounding communities. Because is the level of TDS (ppt) water is too large wil have an impact on the surrounding communities who drank the water.

\section{Research Methods}

This research was conducted around 10 days between May to June 2016. laundry liquid waste samples taken in 10 home laundry businesses around East Jakarta such Pulo Gadung and Pondok Kopi. The tools or the equipment we used in this research is TDS metre (waterproof tester). From 10 samples of laundry liquid waste obtain directed done the analysis to test the content of TDS in laundry liquid waste. With used the temperatures is around $26.40 \mathrm{C}$ to $27.3 \mathrm{C}$. 


\subsection{TDS (ppt) of laundry water chart results}

\section{Result And Discussion}

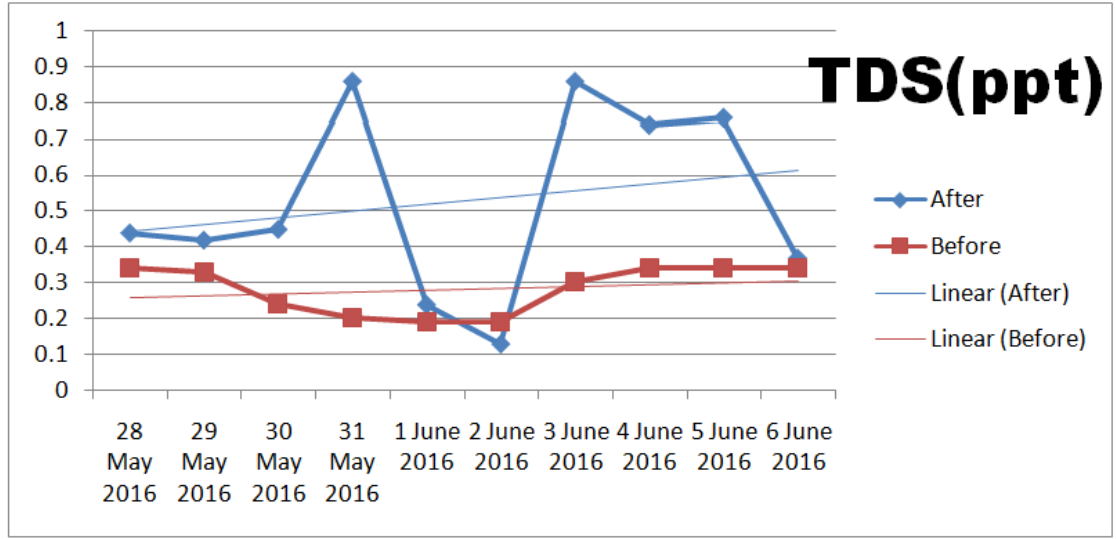

\subsection{Result of the research}

Research conducted by putting samples of laundry water before and after into the plastic container and measure them by using a TDS metre.

\subsection{Before laundry process}

It is been noted that the ground water is said to be normal, if TDS has amount between 0-0.14. On the chart above can be shown that the uses of tap water before the process of laundry uses has a TDS level above 0.19 and below 0.34 . on the 28 May 2016 (Saturday), $4^{\text {th }}$ June 2016 (Saturday), $5^{\text {th }}$ June 2016 (Sunday) and $6^{\text {th }}$ June 2016 (Monday) have the higher TDS level, the amount is 0.35 . As for the date $1^{\text {st }}$ June 2016 (Wednesday), $2^{\text {nd }}$ June 2016 (Thursday) have the lower TDS level the amount is 0.19 and the liner on the tap water tent to high.

\subsection{After the laundry process}

On the chart above can be shown that the water after been used on the laundry processed have the TDs amount around 0.13-0.86. It was seen the higher of the increase on the $31^{\text {st }}$ May 2016 (Tuesday) and $3^{\text {rd }}$ June 2016 (Friday) the amount is 0.86 . As for the date $2^{\text {nd }}$ June 2016 (Thursday) have the lowest TDS level the mount is 0.13 and the liner of the laundry liquid waste id tend to high.

\subsection{Data of analysis}

Result of the research can be shown which the TDS level amount on $31^{\text {st }}$ may 2016 (Tuesday) and $3^{\text {rd }}$ June 2016 (Friday) have the higher TDS level amount, the amount is 0.86 (above pure and clear water) because water TDS level is tend to high. This is caused by the withdrawal of the laundry liquid waste which had contain detergent, fragrance, or the high amount of bleach, and dirt from the clothes that have been rinse with unfiltered by the soil/ground surface. As for date $2^{\text {nd }}$ June 2016 (Thursday) has a huge decrease in TDS level. This is happen because the TDS level has been decreased experience from the withdrawal of the laundry liquid waste. It can be seen on the $2^{\text {nd }}$ June 2016 (Thursday) until $4^{\text {th }}$ June 2016 (Saturday), the TDS level on the water bit by bit getting higher or increase which could be caused by the process of the laundry user was increased.

As for the water have been used by process of the laundry used have been increase to the higher TDS level on the $3^{\text {rd }}$ June 2016 (Friday) the amount is 0.86 . The level seem high, it caused by the amount of using detergent, fragrance, and the high of dirt from the clothes, also it was because the increasement from the process of laundry user is higher than the average or usual.

As shown from the liner of 2 chart above it have be high (TDS been increase). This is not only because detergent that influential in the level dissolved solid in laundry liquid waste. One of factor that cause the liner tend to increase in because there is another compounds that are plastered in the dirty clothed, example is a fat or sweat also dust which contain metal that plastered or sticked in the clothes. It could be cause the 2 liner of the chart goes higher or been increase.

\subsection{Conclusion}

\section{Conclusion And Suggestions}

Based on the results of the research it can be concluded that dissolved solids level in the East Jakarta Area.

1. The levels of the solids the one have been dissolved in the tap water deliver from ground water tend to be good with TDS range between $0,19-0,34$. 
2. The levels of dissolved of solids in the laundry liquid waste range from $0.13-0,86$ are included in the category not good.

3. The second liner chart (process of the laundry water before and after the process of laundry) tends to increase

\subsection{Suggestions}

There is need socialisation to housing industry whose runs the laundry business about the qualities of ground water surrounding their business which can be impact on the surround communities.

\section{Refferences}

[1]. H.Z. Abidin, R. Djaja, D. Darmawan, S. Hadi, A. Akbar, H. Rajiyowiryono, Y. Sudibyo, I. Meilano, M. Kasuma, J. Kahar, Land subsidence of Jakarta (Indonesia) and its geodetic monitoring system, Publisher, City, 2001.

[2]. S. Sudarmadi, S. Suzuki, T. Kawada, H. Netti, S. Soemantri, A.T. Tugaswati, A survey of perception, knowledge, awareness, and attitude in regard to environmental problems in a sample of two different social groups in Jakarta, Indonesia, Publisher, City, 2001.

[3]. J.J.-G. Chen, H.-L. Lee, An ergonomic analysis system for laundry industries, Publisher, City, 1994.

[4]. L. Manni, K. Jellouli, O. Ghorbel-Bellaaj, R. Agrebi, A. Haddar, A. Sellami-Kamoun, M. Nasri, An oxidant-and solvent-stable protease produced by Bacillus cereus SV1: application in the deproteinization of shrimp wastes and as a laundry detergent additive, Publisher, City, 2010.

[5]. S. El Haggar, Sustainable industrial design and waste management: cradle-to-cradle for sustainable development, Academic Press, 2010.

[6]. F. Steinberg, Jakarta: Environmental problems and sustainability, Publisher, City, 2007.

[7]. M.D. LaGrega, P.L. Buckingham, J.C. Evans, Hazardous waste management, Waveland Press, 2010

[8]. W. Tritt, F. Schuchardt, Materials flow and possibilities of treating liquid and solid wastes from slaughterhouses in Germany. A review, Publisher, City, 1992.

[9]. T. Izzati, P. Hastuti, I. Gunawan, E. Sukmawijaya, Social Welfare Programs For Young Society In Indonesia, Publisher, City, 2015.

[10]. T. Izzati, P. Hastuti, I. Gunawan, E. Sukmawijaya, An Education Profile Of Indonesian Youth In 2009-2013, Publisher, City, 2015.

[11]. J.G. Dean, F.L. Bosqui, K.H. Lanouette, Removing heavy metals from waste water, Publisher, City, 1972.

[12]. W.Z. Tang, Physicochemical treatment of hazardous wastes, CRC Press, 2016.

[13]. J. Stauffer, The water crisis: Constructing solutions to freshwater pollution, Routledge, 2013.

[14]. P. Sinha, P. Panicker, R. Amalraj, V. Krishnasamy, Treatment of radioactive liquid waste containing caesium by indigenously available synthetic zeolites: A comparative study, Publisher, City, 1995.

[15]. J.B. Robertson, R. Schoen, J.T. Barraclough, Influence of liquid waste disposal on the geochemistry of water at the National Reactor Testing Station, Idaho: 1952--1970, in, Geological Survey, Idaho Falls, Idaho (USA). Water Resources Div., 1974

[16]. T. Izzati, Y. Poerwanti, Enhancing The Productivity And Multifunctionality Of Open Space Using Simple Techniques In Green Buildings, Publisher, City, 2014.

[17]. J. Kanagaraj, T. Senthilvelan, R. Panda, S. Kavitha, Eco-friendly waste management strategies for greener environment towards sustainable development in leather industry: a comprehensive review, Publisher, City, 2015.

[18]. N.L. Nemerow, F.J. Agardy, Strategies of industrial and hazardous waste management, John Wiley \& Sons, 1998. 